\title{
BUSINESS PROCESS REENGINEERING - THE ROLE OF HUMAN RESOURCE FUNCTION: A COMPREHENSIVE REVIEW OF LITERATURE
}

\author{
SUPRIYA BHASIN ${ }^{1} \&$ S. S. DHAMI ${ }^{2}$ \\ ${ }^{1}$ Amity School of Business, Amity University, Noida, Uttar Pradesh, India \\ ${ }^{2}$ Department of Mechanical Engineering, National Institute of Technical Teachers
}

Training and Research (NITTTR), Chandigarh, India

\begin{abstract}
Business Process Re-engineering (BPR) is the fundamental rethinking and radical redesign of business processes to achieve remarkable improvements in critical measures of performance such as cost, quality, service, and speed. In the Banking industry, BPR means transforming processes and procedures to empower the bank with the human resources, technologies, business solutions and innovations that enhance its competitive advantage. There is no doubt about the critical role which Information technology (IT) plays in the success of BPR. Along with that, studying the related human resource issues of resistance to change and the perception of the impact of BPR on their jobs is attracting the attention of the academicians and practitioners. Research is increasingly giving importance to using effective change management techniques and treating human factors at par with IT to improve the success ratio of BPR led changes. The purpose of this paper is to analyze the past and shed light on the future scope of the role of the human resource function in BPR in banks. This is achieved through a review of literature published covering the period from the 1990s to 2018. This paper reviews the literature under the main fields of concept and evolution of BPR, the scope of BPR in banks, BPR and HR coexistence and the change management challenge. Finally, gaps in literature have been identified and suggestions given for future research opportunities.

KEYWORDS: Business Process Re-Engineering, Literature Review, Human Resource Function, Banking Sector \& Change Management
\end{abstract}

Received: May 14, 2018; Accepted: Jun 04, 2018; Published: Jul 02, 2018; Paper Id.: IJBMRAUG20181

\section{INTRODUCTION}

For almost three decades, there has been a considerable focus of literature on Business Process Re-engineering (BPR). Business process re-engineering (BPR) has been visualized as a radical concept to help business houses to rethink their current processes from the basics in order to radically improve them so that it phenomenally cuts costs, leads to better customer service and enables them to compete globally.

Nowhere has the story of BPR inspired success been more profound than in the Banking Sector which has shown remarkable progress in the last few years. As a result of the changes in the markets initiated by liberalization and globalization and technology acting as the catalyst, the pace of transformation of Banking has been extremely rapid in the last 2-3 decades. With the growing use of Information Technology to make banking more personal by offering a host of services to the customers, banks are not only redesigning their current business processes but also re-defining the rules of the game by innovative banking practices through Business Process Re-engineering. 
It is important to note that the failure of BPR in organizations has been as severe as its success stories. Related research points towards the need for effectively conveying an understanding of the 'need for cultural change' to the people by the top management. This is essential to keep people feel motivated enough. Also, there is growing focus on the criticality of 'Change Management' which involves the techniques to be implemented by the management during the BPR implementation process keeping in consideration that workforce is People, not programmable machines.

This paper presents a review of the existing literature on the role of human resource function in BPR, also with specific reference to banks. The aim is to provide the reader an understanding of what has been the extent of the role played by people in BPR programs of banks. Such insights can also help in the better utilization of the potential of human resources in BPR to give the banks a sustainable competitive edge with happy employees and happier customers. The review covers articles which have been published in leading academic journals, professional business magazines, and books which are available in print or an online edition. Based on the rapidly changing nature of banking and the resulting human resource challenges faced by banks, a comprehensive review is necessary to help researchers as well as senior bank executives to focus on areas/practices which are crucial for optimizing the benefits of BPR initiatives. No recent review papers could be found in this area that had done a systematic analysis of recent literature to identify critical and future avenues. This paper is an endeavor to cover these gaps in the literature by reviewing, categorizing and analyzing research covering a period from 1990s to 2018. Moreover, an additional aim of this paper is also to identify areas for future research. Amongst other sources of literature, 154 research papers were selected for review. About 70 references have been cited and listed at the end of this paper. After reviewing the literature, four major issues have been identified worthy of a detailed discussion in this paper:

- Concept and Evolution of BPR: This section examines the history, evolution of the concepts, successes, and failures of the re-engineering projects.

- A scope of BPR in Banks: This section examines the status of BPR in the banking sector and its transformational role played.

- The Co-Existence of BPR and HR: This section discusses the traditional role that has been played by the Human Resource function in organizations and its criticality specifically with respect to BPR projects in banks.

- The Challenge of Change Management: This section analyses the importance of effective Change Management to realize the full potential of BPR.

Before analyzing the above areas, the paper begins with a discussion of how banks have been re-engineering their business processes. The significance of the role of human resource function has also been discussed. The paper concludes by identifying potential research topics relating to the role of human resources in business process re-engineering.

\section{Business Process Reengineering in Banking Sector}

The world was introduced to the concept of BPR in the year 1990 when Michael Hammer, a former professor of computer science at the Massachusetts Institute of Technology (MIT), published the article "Reengineering Work: Don't Automate, Obliterate" in the Harvard Business Review. In this, he had emphasized that the main challenge for managers was to obliterate any work that does not add value, instead of automating it using technology (Hammer, 1990) [27]. This fundamental shift of focus from the existing structures/ways to a new perspective started appealing to many renowned management thinkers and subsequently, research started being conducted in BPR. A growing amount of BPR related 
literature coupled with the intense competition and falling profit margins provided fertile ground for many consulting firms to interpret this concept in their own way and formulate methods to enable their clients (organizations) to achieve major breakthroughs. The two most widely acceptable and comprehensive definitions of Business Process Reengineering were given in its formative years itself:

"Is the fundamental rethinking and radical redesign of business processes to achieve dramatic improvements in critical contemporary modern measures of performance, such as cost, quality, service, and speed." (Hammer and Champy, 1993) $[\underline{26}]$

"Encompasses the envisioning of new work strategies, the actual process design activity, and the implementation of the change in all its complex technological, human, and organizational dimensions." (Davenport, 1993) [14]

In the banking industry, Business Process Re-engineering (BPR) means transforming selected processes and procedures to empower the bank with up to date personnel, information technologies, business solutions and innovations which enhance the competitive advantage. Common business processes of a bank include opening an account, cheque transfers, credit card/debit card approvals, loan disbursements etc. The broad objectives of BPR initiatives in banks have been to build long lasting and satisfying relationships with customers, to acquire new customers while retaining those already associated with the bank, to drastically increase the volume of business, improve productivity and profit per employee and last but not the least, to enhance the levels of customer service and experience by developing multiple delivery channels and simplifying processes to the maximum. To achieve these objectives, central processing centers (IT) and customized products form the core pillars of BPR in a bank. There is no doubt that the success saga of BPR in the banking sector has been so far impressive. Concepts like Core Banking, digital platforms like the online and mobile banking, ATM deployments etc have resulted in a flourishing sector focused on technological innovations.

In the Indian context, the Case Study of SBI merits a particular mention in the category of Public Sector Banks. To remain competitive with its private sector counterparts, the State Bank of India (SBI) - the largest and oldest bank in India began the largest implementation of a centralized core system in the year 2002. The implementation of the Tata Consultancy Services (TCS) BaNCS Core Banking at SBI and its affiliate banks represents the largest centralized core system implementation ever undertaken. Although SBI had intended to convert only 3,300 branches, the stupendous success made it expand the project to include all of the more than 14,600 SBI and affiliate bank branches. It helped the bank to achieve its goal of offering a full range of products and services to all its branches and customers, spreading economic growth to rural areas and providing financial inclusion for the vast majority of Indian citizens. (Source: Tower Group Research Note V58:06R, Case Study: SBI - World's Largest Centralized Core Processing Implementation, Feb 2009).

In Private Sector, the case of ICICI Bank (formerly Industrial Credit and Investment Corporation of India) stands out for its thumping success post-BPR led initiatives. ICICI Bank is the largest private sector bank in India by market capitalization and a proud member of the Big 4 banks of India - The others being The SBI, Axis Bank and HDFC Bank which are also its main competitors. Post the year 2000, INFOSYS, the technology partner of ICICI Bank gave it Finacle - A core banking and universal banking solution. Its successful implementation gave ICICI Bank a platform to handle all the activities of its $1700+$ branches. Finacle successfully managed the increase in transaction levels from 400,000 transactions a day in 2000 to nearly 2.1 million by 2005 with an associated growth in peak volumes by 5.5times. As a result, ICICI Bank grew immensely over a period of time and became the first private bank in Indian history to merge 
with a public sector bank - Bank of Rajasthan through the share swap in a non cash deal. With Finacle, the bank currently has the ability to process 0.27 million cheques per day and manage 7000 concurrent users. (Source: http://www.infosys.com/finacle/customers/case-studies/Pages/investment-in-technology.aspx)

Nevertheless, it is noteworthy to consider few points as mentioned in a Report presented in January 2014 by EY in collaboration with the Indian Banks Association titled: "Banking on Technology - Perspectives on the Indian Banking Industry" [19]. The following observations deserve focus: "most core banking programs have been focused on internal functioning....rather than adopting a holistic business process re-engineering paradigm....Internet and mobile banking enrolment and adoption....is significantly low....technology are yet to make a dent in the lives of millions of financially excluded Indians...." Clearly, while the banking system has done well in adjusting to the new market dynamics through the extensive use of technology, greater challenges lie ahead. A strong impetus to the growth of banking sector is set to be given by the vibrating and impressively growing national economy. A BRICS Report pegged impressive growth rates for our economy (TBP and Agencies, 2015) [10]. This figure was the highest this report quoted for any country's economy. Also, the aspect of financial inclusion of the majority of people of our country untouched by banking so far is taking a center stage with the launch of programs like the Pradhan Mantri Jan Dhan Yojana (PMJDY was launched in Aug 2014) (ET Bureau, 2014) [20]

Global on-field experiences and the literature concerning banking reforms and issues related to various aspects of BPR in Banking Sector suggest a pressing need for an aggressive use of BPR to further the strategic goals of banks. All of which points to the growing realization of the importance of effectively harnessing the immense potential of 'human resources' to gain an edge over the competitors.

\section{Role Played by the HR Function in BPR}

Since reengineering involves a multitude of human resource challenges, it provides the HR department with a golden opportunity to put its stamp on an organization. "It's up to HR to take the initiative and define its role," says Janet Caldow, a senior consultant at IBM Consulting Group in White Plains, New York. "In most cases, things aren't clearly defined during a re-engineering project. Those who step forward gain the opportunity to blaze the trail." Various experts are of the opinion that the HR executives can provide invaluable guidance and direction to any project as it unfolds (Greengard, 1993) [23].

The concept of BPR was very different from approaches like Organization Development (OD) or Total Quality Management (TQM) (Johansson et al.., 1993) [34] The essence of BPR was propounded in its aim for radical change which was markedly different from the incremental improvements which were the goals of TQM philosophy or the change in organization structure(s) as suggested by OD practitioners. However, the true spirit of BPR and its concepts continued to be misinterpreted and ill-defined at the worst and ambiguous at the best for very long. Nevertheless, driven by a cut-throat competitive environment and reducing operating margins, re-engineering continued to be embraced and in the initial few years of its birth, as many as $60 \%$ of the Fortune 500 companies claimed to either has initiated re-engineering efforts or to have plans to do so (Hamscher, 1994) [료

Not long after, critics started accusing BPR of dehumanizing the basic concept of work, slyly increasing the managerial control and being a ploy of the organizations to downsize. The critique was not entirely unjustified as in few cases, massive reductions of the workforce was the most striking outcome (As illustrated in Ford's Accounts Payable Case 
Study wherein the number of staff was reduced from 500 to a mere 125 post re-engineering practices) (Alameemi et al., 2014) [4]. The rising negativity and non-clarity regarding its objectives gradually fueled the decline of the BPR fervor. In their endeavors to analyze the most common causes of success and failures of BPR projects, researchers had traditionally been over-emphasizing the role of IT in the success of BPR projects while attributing the failures majorly to the 'confusion surrounding BPR and its implementation' often overlooking the most important aspect of 'People'. Though IT has played a major role in the re-engineering projects, learning from early debacles, some BPR proponents emphasized to incorporate an assessment of the impact that BPR could have on jobs (Roberts, 1994) [54] and started laying stress on use of effective change management tools to manage the resistance to change which had been responsible for the failure of majority of the BPR projects. It began to be realized that if human factors are treated at par or greater than IT and process redesign factors, the success ratio of radical business transformation through BPR would increase substantially.

As indeed since any BPR project affects the culture, behavior, organization structure and work-processes, it would be catastrophic to under-estimate the importance of the 'human' role in implementing the related changes. After all, these are the very factors driving the implementation of BPR and if not taken into account properly can withhold the innovation and the willingness to improve the existing systems (Al-Mashari and Zairi, 2000) [6] Hammer eventually did admit: "I wasn't smart enough about that. I was reflecting on my engineering background and was insufficiently appreciative of the human dimension. I've learned that's critical." (Watts, 1994) [66]

\section{LITERATURE REVIEW}

This study has attempted to analyze 154 research publications published between 1990 and 2018 as illustrated in Figure 1.

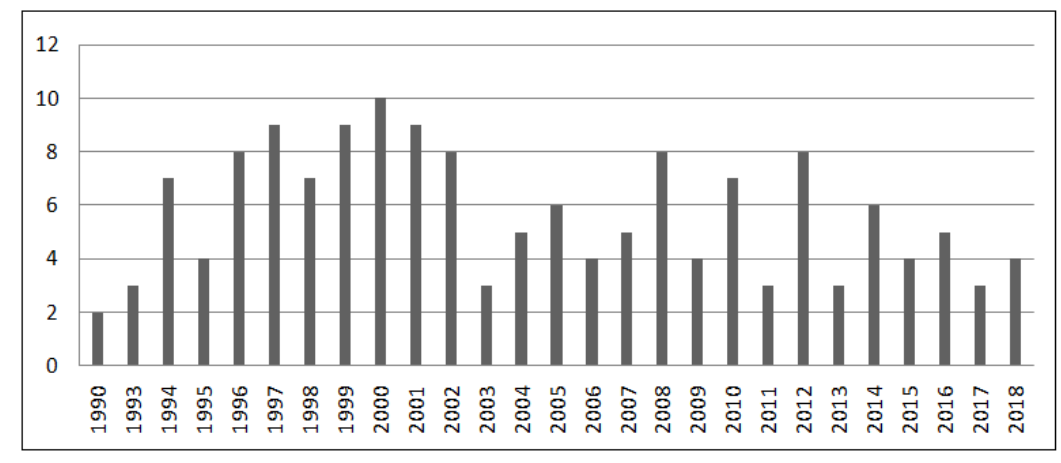

Figure 1: Distribution of Publications per Year across the Period of Study (154 Papers: 1990-2018)

Figure 2 presents the number of papers in different sub-areas of the study. The studies describing the criticality of IT in BPR are numerous. Most of the literature extols the virtues and indispensability of IT tools to achieve BPR success across industries. However, the latest BPR exercises are more readily available as news clippings and articles appearing in the magazines. 


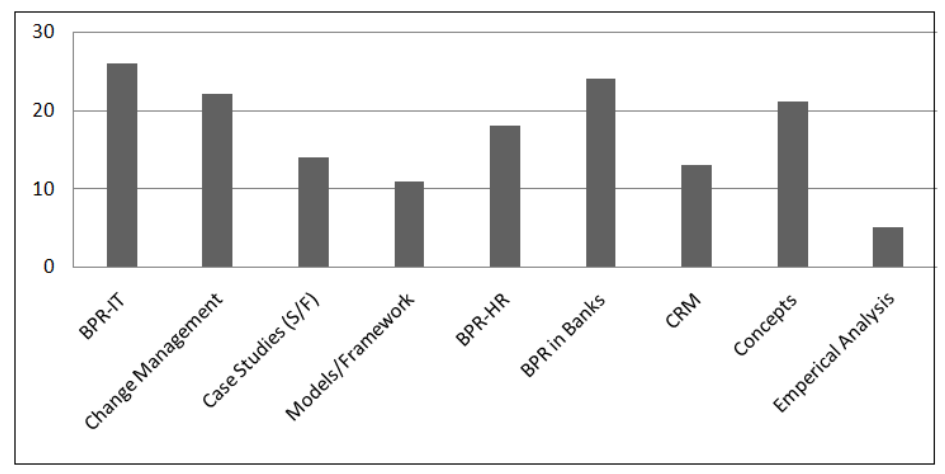

Figure 2: Sub-Areas of the Research Papers Constituting the Study (154 Papers: 1990-2018)

The number of research papers and their distribution among the journals is presented in Table 1. The Business Process Management Journal, ISSN: 1463-7154 (formerly Business Process Reengineering \& Management Journal) is a peer-reviewed academic journal that covers the field of quality management. It has been online from 1997and is published by the Emerald Group. This journal remains the most sought after for the in-depth study of any sub-area of BPR.

A careful review of the table reveals that the subjects of BPR/Role of HR in BPR have been considered by diverse journals. 154 papers were found in various journals with few publications having two or below the number of papers in the fields of study. Selected papers of this literature review have been analyzed and discussed to form a comprehensive view of the studies. The results can clarify the gaps and give an indication of the future directions of research. Above 70 references have been cited and listed at the end of this paper.

Table 1: Distribution of Research Papers based upon the Source of Publication

\begin{tabular}{|l|c|c|c|c|c|c|}
\hline \multirow{2}{*}{ Publication } & \multicolumn{5}{c|}{ Year of Publication } \\
\cline { 2 - 7 } & Upto 2000 & $\mathbf{2 0 0 1 - 2 0 0 5}$ & $\mathbf{2 0 0 6 - 2 0 1 0}$ & $\mathbf{2 0 1 1 - 2 0 1 5}$ & $\mathbf{2 0 1 6 - 2 0 1 8}$ & Total \\
\hline Business Process Management Journal & 6 & 8 & 7 & 5 & 7 & 33 \\
\hline International Journal of Bank Marketing & 3 & 4 & 5 & 3 & 0 & 15 \\
\hline The TQM Magazine & 4 & 3 & 3 & 4 & 0 & 14 \\
\hline Personnel Review & 3 & 5 & 4 & 0 & 0 & 12 \\
\hline Journal of InternetBanking and Commerce & 6 & 4 & 5 & 3 & 2 & 20 \\
\hline Managing Service Quality: An International Journal & 4 & 5 & 3 & 4 & 0 & 16 \\
\hline $\begin{array}{l}\text { International Journal of Marketing, Financial Services } \\
\text { and Management Research }\end{array}$ & 5 & 4 & 4 & 0 & 0 & 13 \\
\hline Journal of Organizational Change Management & 3 & 3 & 4 & 0 & 1 & 11 \\
\hline Others (2 and below) & 5 & 4 & 6 & 4 & 1 & 20 \\
\hline \multicolumn{1}{|c|}{ Total } & 39 & 40 & 41 & 23 & $\mathbf{1 1}$ & 154 \\
\hline
\end{tabular}

As mentioned in the introduction, a literature review is further grouped into four parts as follows.

\section{Concept and Evolution of BPR}

While Hammer and Champy (1993) [26] promoted the fundamental rethinking and radical redesign of the business processes to achieve drastic improvements in measures of performance viz. cost, quality, service and speed, Short and Davenport (1990) [58], on the other hand, described BPR as the analysis and design of the workflows and process within and between the organizations. Talwar (1993) [63] focused on the re-thinking, restructuring and streamlining of the business structure, processes, and methods of working, management systems and external relationships. Many other authors have given their own interpretation regarding the definitions, concepts and what constitutes BPR. Eierman and Schultz (1995) [18] made a detailed attempt at not only defining what BPR is, they also elucidated what exactly it is not viz. how BPR is different from Business transformation or Systems reengineering or TQM. They concluded their analysis 
by making a pertinent suggestion that people are more important than the methodology to ensure success in BPR projects.

Grover et al., (2000) [24] opined that optimizing processes at the cost of people is the major problem of reengineering and that the two divergent thought streams - the strong position of radical change which is the essence of BPR and continuous improvement as advocated by TQM are converging. According to them, the classical 'greenfield' approach to re-engineering advocating an almost revolution fever can not last forever because to become sustainable, re-engineering has to become more inclusive and accommodating.

Other authors such as Kohlborn et al., (2014) [36] in their interview with Professor Michael Rosemann, (one of today's authorities in the BPM field, who shared his thoughts on ambidextrous BPM) focused on Explorative BPM, which emphasizes radical process change, process innovation and the enabling of new business models. Deakins and Makgill (1997) [15] on the other hand, believed that of particular concern, is the lack of attention given to so-called "people issues". O'Neill and Sohal (1999) [46] gave a critique of the existing literature regarding the definition of BPR, BPR and TQM coexistence, BPR tools and techniques, the re-engineering challenge, understanding organizational processes, and organizational design using BPR. A survey of 220 mid-level professionals in 123 organizations was conducted by Gore Jr (1999) [22] to determine the extent to which there is a relation between the presence of the 'Organization culture' element, and the presence of TQM or re-engineering, and it was found that the success of process improvement through either TQM or re-engineering is used as a vehicle for examining the importance of these cultural elements. Specifically, three elements of culture related to quality improvement: customer focus, employee involvement, and continuous improvement were examined.

To study the BPR implementation process and analyze key success and failure factors, Al-Mashari and Zairi (1999) [5] gave a review of the literature relating to the hard and soft factors that cause success and failures, classified these factors into subgroups, and identified key factors of success and failure. A few factors for success were characterized as a revision of reward systems, communication, empowerment, people involvement, training and education, creating a culture for change, and stimulating receptivity of the organization to change, top management support and commitment etc. Among the factors described as reasons for failure, problems related to commitment, support, and leadership, organization resistance for change, problems in communication, organization culture or a lack of it figured prominently.

Porter (1996) [51] gave a very far-reaching description of Operational Effectiveness "which means performing similar activities better than rivals" which is different from Strategy "which means performing different activities from rivals or performing similar activities in different ways". While there is confusion regarding the benefits of any BPR exercise in the real terms, Altinkemer et al., (2011) [9] investigated whether business process reengineering (BPR) is related with improved firm productivity and overall performance. This was achieved by analyzing data on BPR projects conducted by large U.S. firms in the Fortune 500 list covering the period between 1987 and 2008. Results indicated that one of the key performance variables - return on assets - drops significantly during the project initiation year. Evidence also suggested a negative impact on firm performance in the first year of BPR projects and in some cases the impacts were felt immediately, especially in enterprise-wide implementations. From then on, however, it was observed that some of the firm performance measures improve in a decreasing manner and peak within two to ten years in general. IT investments were found to have the most impact on the firm after a lag of two to three years because the impacts of new technology are not fully felt immediately.

Van der Aalst et al., (2016) [64] argued that there has frequently been an excessive focus on process models in 
Business Process Management. They stated that better models do not automatically yield better processes and that the research should be more focused on the original goal of improving business processes, rather than improving process models. An interesting study by AbdEllatif et al. (2017) [1] proposed Process Reengineering Ontology-based knowledge Map Methodology (PROM) to reduce the BPR failure ratio and overcome the difficulties and problems of BPR. The study proposed using the organizational ontology to show the structure and environment surrounding to organization's processes and then using knowledge maps to identify and find out the causes that lead to contradictions and inefficiencies in BPR.

The resistance of employees to BPR programs is caused by poor communication, lack of organizational maturity, lack of technical skills among employees, conflict in organizational traditions and ideologies, lack of perceived benefits, fear of losing power and weak project leadership as illustrated by Taher and Krotov (2016) [62]. Using the case study of Natural Springs, a Russian startup company, the authors explained that these factors can lead to sabotage of business process reengineering initiatives by tactics such as deflecting goals, diverting resources and dissipating energies. They concluded that strong leadership, stakeholder impact analysis, establishing reward and deterrence mechanisms and effective communication amongst other strategies can be used to counter these sabotage tactics.

\section{The Scope of Business Process Reengineering in Banks}

In the banking sector, BPR incorporates transforming selected procedures and processes to empower the bank with contemporary technologies, innovative business solutions and cutting-edge technologies to enhance the competitive advantage on a sustainable basis.

Authors Küng and Hagen (2007) [40] used four processes to explain the BPR approaches implemented in a Swiss Bank. They depicted that through the combination of process restructuring and the application of modern IT, processes can be improved significantly. Ringim et al., (2012) [53] analyzed the implementation of BPR in Nigerian Banks. Their study found that Nigerian banks surveyed have re-engineered their branch operations, customer services, cash telling services, cheque's clearing, domestic fund transfer, loan processing, credit administration, and appraisal. Second, their results showed that the maximum number of the surveyed banks agreed that enhancement of profit is the most objective of BPR implementation followed closely by banks that are of the opinion that improvement over the quality of customer service is the most objective of BPR adoption.

A significant literature of BPR in banks focuses on the investigation of the BPR methods best suited for financial institutions. Shin and Jemella (2002) [57] conducted a case study in Chase Manhattan Bank in the US and found that the Chase BPR projects included Name and address re-engineering, branch cash management, e-fund disbursement cards, service charge reengineering, retail funds transfer re-engineering and centralized account holds and levies. These efforts not only resulted in new products and services but also produced spectacular increases in revenue and operating savings. Their research attempted to present guidelines for BPR projects in financial institutions that will help them achieve impressive performance gains.

Drew (1996) [17] considered improvements in customer service quality, cycle-time, head-count, and cost measures as the drivers to accelerate change in the financial sector. In other studies, the acceptance of BPR was reinforced by the implementation of re-engineering initiatives in many Malaysian banking institutions (Khong and Richardson, 2003) [35]. The aim of their study was to investigate the effectiveness of the critical success factors (CSFs) of BPR implementation process in the Malaysian banks and finance companies. Another study by authors Islam and Ahmed (2012) 
[33] aimed to study the shortcomings of the business process of credit card department of a multinational bank. Using case study methodology, the authors collected primary data through interviews of individuals, focus groups and secondary data from company documents. Using SWOT analysis, Fishbone Diagram, Process Flow Diagram and a number of other tools, the authors analyzed and redesigned the existing process. The research identified that business process of the credit card department of a multinational bank is unnecessarily lengthy and the authors proposed a to $\square$ be business process for the same business function that would reduce half of the time of the existing process thereby using the organizational resources efficiently to achieve better customer satisfaction.

In other related literature, authors Kumar and Motwani (1999) [39]demonstrated, by means of a case study, how a Midwest bank in the USA took a proactive approach and turned things around. According to McCabe and Knights (2000) [42], the neglect of people in BPR has resulted in "operational" managers being forced to address issues such as low staff morale, poor job satisfaction and high levels of stress after a new structure or system has been put in place. The main objective of the study by Onjure et al. (2018) [48] was to analyze the influence of organizational capabilities on ecommerce strategy as adopted by commercial banks in Kenya. After an in-depth study of the following constructs; business process re-engineering, structural design, capacity for change, and leadership, they concluded that Structural Design, capacity for change and Leadership have a higher influence on Electronic Commerce strategy adoption of banks.

In an empirical study, Selvam (2017) [55] evaluated the level of awareness on phone banking services among the customers of Indian commercial banks. The author attempted to identify the factors influencing the usage of phone banking services. According to his study, customers' perception and level of awareness on individual E-Banking channels, ATM, and mobile banking is good. Some of the most satisfying services according to the Banks' customers under study were cash withdrawal and balance inquiry facilities in ATM channel, SMS alerts, and funds transfer in mobile banking services and viewing account balance and online bill payment in internet banking. The shift towards internet banking is fuelled by the changing dynamics in India as stated by Sharma (2016) [56] in her study to analyze and examine the progress of Internet Banking in India. The author stated that by 2020 the average age in India will be 29 years. According to the author, this young consumer base would be highly internet savvy and would want real-time online information. Indian banks therefore, need to move towards implementing a world-class internet banking capability. The author added that despite the more than positive predictions and increased corporate activity; the Indian Internet banking system has been facing many hurdles - operational risks, security risks, system architecture risks, reputational risks and legal risks.

Most of the literature suggests that BPR can benefit the customers through significantly reducing the transaction time and improving flexibility in service. The banks can be benefited by the increased volume of business and higher productivity reduced operational costs leading to higher profits, greater employee loyalty and a sense of belongingness.

\section{The Coexistence of BPR and HR}

The various definitions and concepts of BPR point to a common theme that proper implementation of BPR is quite difficult without due consideration towards 'human issues'. Zucchi and Edwards (1999) [71] derived a number of propositions relating to aspects of human resource management from the literature and examined by interviewing senior Managers in UK organizations where business process re-engineering projects had either been completed or were still in progress. The propositions were analyzed under four major headings: structure and culture, the role of managers, team working, and reward system. Overall, the organizations studied which have undergone BPR, a very clear pattern emerged with respect to human resource management practices. 
BPR's cursory treatment of the human function was best highlighted by Willmont (1994) [68] who posed several significant questions of how the HRM specialists are supposed to act in response to the blatant neglect of the human role for successful organization change through BPR. In another study, Willmont (1995) [69] suggested that though at the outset, HRM and BPR may appear as the odd couple they have a lot of similarities. He reiterated that as the unintended negative consequences of the neglect of human dimensions become more and more apparent in the organizations, there would be an increasing prominence on identifying HRM-type techniques to lessen the ill-effects of reengineering outcomes on employee commitment and good-will.

Hin (2005) [31] tried to assess the status of BPR in China by seeking answers to two fundamental questions: How are Chinese businesses viewing the benefits, the critical success factors, the major obstacles of BPR implementation in their organizations; and what are the various implications of BPR in China. By using data collected by means of survey questionnaires to senior managers in Beijing and Shanghai, his statistical analysis results indicated that while BPR has played a significant role in making the enterprises in China more efficient, valuable and competent; the implementation aspect had been jagged among various business sectors and ownership. He enlisted management support, cross-unit project team, cross-functional communications and measurable BPR objectives at the top of the list of the critical success factors. The top four obstacles presented were a culture that resists changes \& new ideas, seniority and not performance -based promotion, lack of innovation incentives to state-owned enterprises and the pressure of unemployment. Korde and Laghate (2013) [37]studied the impact of training on the performance of selected two Public Sector Banks, i.e. Bank of Baroda and Union Bank of India. The authors arrived at the conclusion that the bank which had invested more in training was able to perform better than the bank which invested comparatively less in the area of training and especially in the area of HR and NPA related training.

To examine the similarity of human resource practices in re-engineered organizations, Zucchi and Edwards (2000) [72] presented a paper on the commonalities that emerged with respect to HRM practices as a "typical" pattern, anda "vertical analysis" was carried out to compare the individual organizations studied with this pattern. The role of creativity in business improvement paradigms was studied by Paper et al. (2000) [50]. The purpose of their research was to explore the role of creativity (in business process improvement paradigms) among Japanese organizations and US organizations. Eight organizations participated in the study: four organizations from Japan and four from the US. The results of the study revealed that US organizations tend to desire faster change to improve performance. They adopted state $\square$ of $\square$ the $\square$ art methodologies and invested heavily in technology to transform their organizations quickly. In contrast, Japanese organizations preferred smaller, incremental changes as it conformed to their culture.

As far as the Indian Banking sector is concerned, The Boston Consulting Group (BCG), FICCI and Indian Banks Association (IBA) (2011) in a report titled “Being Five Star in Productivity: Roadmap for Excellence in Indian Banking” [12] highlighted incredible scope for Indian banks to improve their productivity from the present strong base. The study predicted that Indian banks can be a global benchmark in product excellence and profitability. The Report also observed that the Public sector seems to be holding itself from proper investment advisory to retail customers which can be a costly mistake. It also unfolded the futuristic scenario by spelling that a rapid growth in usage of new channels will characterize the next decade in Indian banking with mobilephones, propelled by 4G/5G and smart phone technology, emerging as the undisputed winner by 2020; potentially accounting for 20-30 percent of the total transactions. These new channels will not only boost the productivity but will be a source of new customer acquisition. 
In a case study of Iran Air, Omidi and Khoshtinat (2016) [47] investigated the effect of technical factors, human factors as well as the effect of organizational culture on implementing business process re-engineering in the Iranian Airlines. After statistically analyzing data obtained from senior, middle and operational managers which constituted the population of the study, the authors concluded that human factors and technical factors strongly affect the implementation of business process re-engineering in Iran Air. Author Greengard (1993) [23] opined that HR can provide direction and valuable guidance to any BPR project as it unfolds. According to the author, HR's expertise can encompass a wide range of areas including shaping the new process, creating new role descriptions and job statements which reflect the new corporate order, working out revised compensation issues, training and developing the workforce, molding the new corporate culture and facilitating seamless communication in the workforce.

In summary, therefore, the role of human resources in BPR projects is extremely crucial as several authors have appeared to suggest. Some authors have also identified the dimensions which would make HRM more effective for the implementation of BPR projects (Naz et al., 2013) [44]. There seems to be little doubt either in theory or practice that the efforts to increase the role of the human factors is crucial to extract the maximum benefits from the BPR exercise.

\section{The Change Management Challenge}

While several authors concentrated on the need to take into account the human aspects in re-engineering, they, in particular, mentioned the management of organizational change. Several literature studies have emphasized that the management of change is the largest and most complex task in re-engineering. Noteworthy amongst them are as follows. Stebbins et al. (1998) [61]studied the integration of multiple change initiatives in Blue Shield of California (BSC). Their article reported on an investigation of a specific system-wide change initiative over three years. BPR, as the BSC example shows, can be a powerful change umbrella. Top-level management involvement and commitment played a critical role throughout the change process.

Al-Mashari et al. (2001) [7] highlighted that despite the widespread adoption of BPR, it has failed in many cases due to the lack of an integrated implementation approach. They mentioned that a huge gap in the literature exists regarding it. In their empirical study, they have attempted to provide a 'frame of reference' to reposition the prevailing practices. They designed a survey to collect the data from a large sample of organizations in the US and Canada. Among the other findings, they assessed that a premium focus was placed on 'Change Management' element of integrated BPR implementation. The empirically backed findings contributed immensely to the existing literature by pointing to important features.

In their exploratory study, Sikdar and Payyazhi (2014) [60] suggested that though it is well known that 70 percent of BPR programs failed due to lack of configuration with corporate change strategy, the problem of alignment of workflow redesign with the organizational change process remained inadequately researched. The authors provided a framework for managing organizational change in a planned manner during workflow revamp. They also attempted to identify the role of the managerial levels in the organization for managing the alignment of the various dimensions during business process change. Gupta (2012) [25]found that most of the Indian public sector banks scored high on the continuity forces and relatively low on the change forces. Most of the Indian private-sector banks studied scored quite high on continuity and also impressively high on change forces making them more competitive. The study suggested a need for public sector banks to focus their strategies on factors affecting change and its management for the improvement of their overall performance in the long run. Xiang et al., (2014) [무] created and tested a new research model that utilizes influential 
constructs to model compound BPR project implementation issues. Their study was done by conducting a survey of 145 managers and executives from medium and large-sized companies in the USA and Canada to validate the model. Empirical findings indicated that all three implementation components viz. change management; process redesign and ICT infrastructure improvement had significant impacts on BPR project successes. However, change management seemed to have the utmost effect.

Other authors such as Hill and Collins (2000) [30] tried to analyze the roles of TQM and BPR in organizational change strategies by a case study investigation. It was concluded that, at the case organizations, TQM and BPR are being regarded as complementary approaches to organizational change rather than being mutually exclusive, as some previous writers had suggested. Hanafizadeh and Osouli, (2011) [29]presented a model in order to identify and select the most appropriate process for business process reengineering (BPR) through evaluation of the degree of change. This model included five soft and hard dimensions, 19 factors, and 44 indicators for measuring the changes. Eventually, the proposed model was put into execution in "recruitment" and "performance measurement" processes in a consulting engineering company.

An interesting insight was given by author Doyle (2002) [16] in his study which examined issues of learning, development, and support. He drew on the findings of an ongoing empirical study into the experiences of those managers and employees responsible for implementing and managing change. Further, he examined the way in which they are trained and developed to make the transition from change "novice" to change "expert". He also discussed the theoretical and practical implications facing those who have to "manage the change managers", with focus on HR strategies. Several authors such as Gardner and Ash (2003) [21] argued that the low level of organizational benefits realized by typical strategic information technology interventions has been a product of poor adoption and implementation practices on the part of senior managers and IT practitioners as they have failed to understand the emergent nature of change in complex organizations.

To summarize, several authors have summarized the barriers to effective change management and the importance of human resource personnel in preparing individuals to accept the radical change that BPR comes along with.

\section{CONCLUSIONS AND AREAS FOR FUTURE RESEARCH}

This paper has presented a review of the literature on the role of human resource function in re-engineering projects in banks. It first discussed the need to study the HR role in the context of BPR in the banking sector and then the selected papers of this literature review were discussed and analyzed.

Surprisingly, most of the literature on BPR has not dwelled upon the theme of any specific roles played by the human resource factors during the introduction of BPR in the respective banks/organizations. The researcher was unable to come across any study exploring as to so far to what extent HR policies have been considered critical for the success of BPR implementation or the kind of cross-functional team relationships that could have had been between the HR function and the BPR project team to augment the value of BPR implementation.

Although a range of topics has been covered as part of change management, there is lack of literature regarding the same as practiced in the banking sector. Empirical research is lacking and it presents an opportunity for further research. Specifically talking about banking sector in India, most of the research is devoted to the Public Sector Banks and there is a dearth of literature on the status/impact of BPR in Private Banking Sector. 
On the basis of the literature review presented in this paper, we identify the following topics which can be researched by academicians:

- The role played so far by the HR executives in BPR programs of companies. Has their role been of importance as a change agent or have they merely acted as change enablers.

- The employees' views (as internal customers) about the changes brought about post-BPR in organizations. What were the greatest apprehensions and how do they assess the impact of the changes on their nature of work.

- The extent to which external customers of banks (clients) have been involved in the BPR process via any feedback mechanism.

- The difficulties faced and the most popular benefits accrued after the various BPR related to technological changes in the way banking is done.

- Lessons learned from the most successful and the unsuccessful BPR projects undertaken in banks and identifying the critical success factors specific to the banking sector.

Meticulous, thorough and empirical based research in the above areas can help in shedding light on how much the banking sector has gained from the BPR exercises and the future path which should be taken to make BPR as a transformational tool in the true sense to benefit the banking sector in real terms.

\section{REFERENCES}

1. AbdEllatif, M., Farhan, M.S., \& Shehata, N.S. (2017). Overcoming business process reengineering obstacles using ontologybased knowledge map methodology. Future Computing and Informatics Journal, 2017, 1-22. DOI: https://doi.org/10.1016/j.fcij.2017.10.006

2. Akamavi, R.K. (2005). Re $\square$ engineering service quality process mapping: e $\square$ banking process. International Journal of Bank Marketing, 23(1), 28 - 53. DOI: http://dx.doi.org/10.1108/02652320510577357

3. Akhavan, P., Jafari, M., \& Ali-Ahmadi, A.R. (2006). Exploring the interdependency between reengineering and information technology by developing a conceptual model. Business Process Management Journal, 12(4), 517 - 534. DOI: http://dx.doi.org/10.1108/14637150610678104

4. Alameemi, A., Alameri, H., \& Alkhyeli, M. (2014). Business Process Reengineering - Ford's Accounts Payable Case Study. Wordpress.com, 3(12).Retrieved from https://bprford.wordpress.com/2014/03/12/business-process-reengineering-fordsaccounts-payable-case-study/

5. Al-Mashari, M.,\& Zairi, M. (1999). BPR implementation process: an analysis of key success and failure factors. Business Process Management Journal, 5(1), 87-112. DOI: http://dx.doi.org/10.1108/14637159910249108

6. Al-Mashari, M.,\& Zairi, M. (2000). Revisiting BPR - a holistic review of practice and development.Business Process Management Journal, 6(1), 10-42. DOI: http://dx.doi.org/10.1108/14637150010283045

7. Al-Mashari, M., Irani, Z.,\& Zairi, M. (2001). Business process reengineering: a survey of international experience. Business Process Management Journal, 7(5) 437 - 455. DOI: http://dx.doi.org/10.1108/14637150110406812

8. Altamony, H., Tarhini, A., Zahran, Dr., Al-Salti, A., Gharaibeh, H.,\& Elyas, T. (2016). The Relationship between Change Management Strategy and Successful Enterprise Resource Planning (ERP) Implementations: A Theoretical Perspective. International Journal of Business Management and Economic Research, 7, 690-703. 
9. Altinkemer, K., Ozcelik, Y.,\& Ozdemir, Z.D. (2011). Productivity and Performance effects of business process reengineering: a firm level analysis. Journal of Management Information Systems, 27(4), 129-161. Retrieved from https://www.fsb.muohio.edu/fsb/directory/vita/ozdemir-BPR-Prepublication.pdf

10. Banerjee, S. (2015, April 10). Banking sector set for transformation: Rajan. The Hindu. Retreived from http://www.thehindu.com/business/Industry/rajan-sees-great-changes-in-banking-sector/article7089690.ece

11. Bartoli, A.,\& Hermel, P. (2004). Managing change and innovation in IT implementation process. Journal of Manufacturing Technology Management, 15(5), 416 - 425. DOI: http://dx.doi.org/10.1108/17410380410540417

12. Boston Consulting Group (BZCG), FICCI and Indian Banks Association (IBA). (2011). Five Star in Productivity: Roadmap for Excellence in Indian Banking. Retrieved from http://docplayer.net/9802687-Being-five-star-in-productivity-roadmap-forexcellence-in-indian-wbanking.html

13. Chan, S.L. (2000). Information technology in business processes. Business Process Management Journal, 6(3), 224 - 237. DOI: http://dx.doi.org/10.1108/14637150010325444

14. Davenport, T.H. (1993). Process Innovation: Reengineering work through information technology. Boston, MA: Harvard Business School Press.

15. Deakins, E., \& Makgill, H.H. (1997). What killed BPR? Some evidence from the literature. Business Process Management Journal, 3(1), 81 - 107. DOI: http://dx.doi.org/10.1108/14637159710161594

16. Doyle, M. (2002). From change novice to change expert: Issues of learning, development and support. Personnel Review, 31(4), 465 - 481. DOI: http://dx.doi.org/10.1108/00483480210430373

17. Drew, S.A.W. (1996). Accelerating change: financial industry experiences with BPR. International Journal of Bank Marketing, 14(6), $23-35$.

18. Eierman, M.A.,\& Schultz, H.K. (1995). Business Process Reengineering: Issues for Research and Practice. American Journal of Business, 10(2), 5 - 12 .

19. Ernst and Young Global Limited \& Indian Banks Association. (2014). Banking on Technology: Perspectives on the Indian Banking Industry. Retrieved from http://www.ey.com/Publication/vwLUAssets/EY-Banking-on-Technology/\$FILE/EYBanking-on-Technology.pdf

20. ET Bureau. (2014, August 28). PM 'Jan Dhan' Yojana Launched; 1.5 Crore Bank Accounts Opened in a Day. Economic Times. Retrieved from http://articles.economictimes.indiatimes.com/2014-08-29/news/53362950_1_prime-minister-narendramodi-life-insurance-cover-7-5-crore-new-accounts

21. Gardner, S.,\& Ash, C.G. (2003). ICT $\square$ enabled organizations: a model for change management. Logistics Information Management, 16(1), 18 - 24. DOI: http://dx.doi.org/ 10.1108/09576050310453705

22. Gore Jr., E. W. (1999). Organizational culture, TQM, and business process reengineering: An empirical comparison. Team Performance Management: An International Journal, 5(5), 164-170. Retrieved from https://doi.org/10.1108/13527599910288993

23. Greengard, S. (1993).HR's Role in the Reengineering Process. Personnel Journal, 72(12), p. $48 H$.

24. Grover, V., Kettinger, W.J., \& Teng, J.T.C. (2000). Business process change in the 21 st century. Business \& Economic Review, 46(2), 14-18. 
25. Gupta, V.K. (2012). Flexible strategic framework for managing forces of continuity and change in retail banking business processes in India. Business Process Management Journal, 18(4), 553 - $575 . \quad$ DOI: http://dx.doi.org/10.1108/14637151211253729

26. Hammer, M.,\& Champy, J. (1993). Re-engineering the Corporation, a Manifesto for Business Revolution. London: Nicholas Brealey.

27. Hammer, M. (1990). Reengineering Work: Don't Automate, Obliterate. Harvard Business Review, July-August, 1990, 104112. Retrieved from https://hbr.org/1990/07/reengineering-work-dont-automate-obliterate

28. Hamscher, W. (1994). AI in Business-Process Reengineering. AI Magazine, 15(4), 71-72. DOI: 10.1609/aimag.v15i4.1113

29. Hanafizadeh, P.,\& Osouli, E. (2011). Process selection in re $\square$ engineering by measuring degree of change. Business Process Management Journal, 17(2), 284 - 310. DOI: http://dx.doi.org/10.1108/14637151111122356

30. Hill, F.M., \& Collins, L.K. (2000). The roles of TQM and BPR in organizational change strategies: a case study investigation. International Journal of Quality \& Reliability Management, $17(6), 614 \quad-\quad 635 . \quad$ DOI: http://dx.doi.org/10.1108/02656710010315210

31. Hin, X.J. (2005). A Comparative Study of Business Process Reengineering in China. Communications of the IIMA, 5(1), Article 3. Retrieved from http://scholarworks.lib.csusb.edu/ciima/vol5/iss1/3

32. Нua, G. (2009). An experimental Investigation of Online banking Adoption in China. Journal of Internet banking and Commerce, 14(1), 1-12. Retrieved from http://www.icommercecentral.com/open-access/an-experimental-investigation-ofonline-banking-adoption-in-china.pdf

33. Islam, S., \& Ahmed, M.D. (2012). Business process improvement of credit card department: case study of a multinational bank. Business Process Management Journal, 18(2), 284 - 303. DOI: http://dx.doi.org/10.1108/14637151211225207

34. Johansson, H.J., McHugh, P., Pendlebury, A.J.,\&Wheeler, W.A. (1993). Business Process Reengineering: Breakpoint Strategies for Market Dominance. John Wiley \& Sons.

35. Khong, K.W., \& Richardson, S. (2003). Business process re $\square$ engineering in Malaysian banks and finance companies. Managing Service Quality: An International Journal, 13(1), 54 - 71. DOI: http://dx.doi.org/10.1108/09604520310456717

36. Kohlborn, T., Mueller, O., Poeppelbuss, J.,\& Roeglinger, M. (2014). Interview with Michael Rosemann on ambidextrous business process management. Business Process Management Journal, 20(4), $634 \quad$ - $638 . \quad$ DOI: http://dx.doi.org/10.1108/BPMJ-02-2014-0012

37. Korde, A., \& Laghate, K. (2015). Is There Any Impact of Training on the Performance of Selected Public Sector Banks? Annual Research Journal of Symbiosis Centre for Management Studies, Pune, 3, 135-154. Retrieved from http://www.scmspune.ac.in/chapter/Chapter\%209.pdf

38. Kruger, D. (2017). Application of Business Process Reengineering as a Process Improvement Tool: A Case Study. 2017 Portland International Conference on Management of Engineering and Technology (PICMET), Portland, OR, 2017, 1-9. DOI: 10.23919/PICMET.2017.8125402

39. Kumar, A., \& Motwani, J. (1999). Reengineering the lending procedure for small businesses: A Case Study. Work Study, 48(1), 6 - 12. DOI: http://dx.doi.org/10.1108/00438029910246741

40. Küng, P.,\& Hagen, C. (2007). The fruits of Business Process Management: an experience report from a Swiss bank. Business Process Management Journal, 13(4) 477 - 487. DOI: http://dx.doi.org/10.1108/14637150710763522 
41. Manoj, P.K. (2016). Bank Marketing in India in the Current ICT Era: Strategies for Effective Promotion of Bank Products. International Journal of Advance Research in Computer Science and Management Studies, 4(3), 103-113.

42. McCabe, D., \& Knights, D. (2000). The human face of re $\square$ engineering in financial services. Managing Service Quality: AnInternational Journal, 10(2), 74 - 78. DOI: http://dx.doi.org/10.1108/09604520010318263

43. Mitra, P.,\& Mishra, S. (2016). Behavioral aspects of ERP implementation: A conceptual review. Interdisciplinary Journal of Information, Knowledge, and Management, 11, 17-30. Retrieved from http://www.ijikm.org/Volume11/IJIKMv11p017030Mitra2069.pdf

44. Naz, A., Azhar, Z., Nawaz, M.,\& Gul, A. (2013). Role of Human Resources Management in the Effectiveness of Business Process Reengineering. Journal of Resources Development and Management, 1(1), 60-64. Retrieved from www.iiste.org/Journals/index.php/JRDM/article/viewFile/9299/9510

45. Newman, K., Cowling, A.,\& Leigh, S. (1998). Case study: service quality, business process re $\square$ engineering and human resources: a case in point? International Journal of Bank Marketing, 16(6), 225 - $242 . \quad$ DOI: http://dx.doi.org/10.1108/02652329810241375

46. O'Neill, P.,\& Sohal, A.S. (1999). Business process reengineering: A review of recent literature. Technovation, 19, $571-581$. DOI: http://dx.doi.org/10.1016/s0166-4972 (99)00059-0

47. Omidi, A.,\& Khoshtinat, B. (2016). Factors Affecting the Implementation of Business Process Reengineering: Taking into Account the Moderating Role of Organizational Culture (Case Study: Iran Air). Procedia Economics and Finance, 36, 425432. DOI: https://doi.org/10.1016/S2212-5671 (16)30058-2

48. Onjure, C.O., Wanyoike, D.M.,\& Mung'atu, J. (2018). Influence of Organizational Capabilities on Electronic Commerce Strategy as Adopted by Commercial Banks in Kenya. International Journal of Innovative Research and Development, 7(1), 135-172. DOI: 10.24940/ijird/2018/v7/i1/JAN18002

49. Pandey, S.C.(2015). Re-engineering rewards and incentives - case of a large state owned bank in India.Strategic HR Review, 14(1/2). DOI: https://doi.org/10.1108/SHR-11-2014-0058

50. Paper, D., Chang, R., \& Rodger, J.A. (2000). The role of creativity in business improvement paradigms: US versus Japanese firms. Journal of Systems and Information Technology, 4(1), 8 - 22. DOI: http://dx.doi.org/10.1108/13287260080000750

51. Porter, M. (1996). What Is Strategy? Harvard Business Review, 74(6), 61-78. Retrieved from https://hbr.org/1996/11/what-isstrategy

52. Razzak, R. (2017). Relationships between Indian Commercial Banks Performance and Organizational Effectiveness. Palma Journal, 16(2), 121-125.

53. Ringim, J.K., Razalli, M.R.,\& Hasnan, N. (2011). Effect of Business Process Reengineering Factors on Organizational Performance of Nigerian banks: Information Technology Capability as the Moderating Factor. International Journal of Business and Social Science, 2(13), $198 \quad$ 201. $\quad$ Retrieved from http://ijbssnet.com/journals/Vol._2_No._13_Special_Issue_July_2011/21.pdf

54. Roberts, L. (1994). Process Reengineering: The Key to Achieving Breakthrough Success. Milwaukee, WI: ASQ Press.

55. Selvam, V. (2017). Impact of information technology in phone banking sector. International Journal of Commerce and Management Research, 3(5), 101-105.

56. Sharma, G. (2016). Study of Internet Banking Scenario in India. International Journal of Emerging Research in Management \&Technology, 5(5), 43-48. 
57. Shin, N.,\& Jemella, D.F. (2002). Business process reengineering and performance improvement: Chase Bank. Business Process Management Journal, 8(4), 351 - 363. DOI: http://dx.doi.org/10.1108/14637150210435008

58. Short, J.E., \& Davenport, T.H. (1990). The new industrial engineering: Information Technology and business process redesign. Sloan Management Review, 31(4), 11-27. Retrieved from https://dspace.mit.edu/bitstream/handle/1721.1/48613/newindustrialeng00dave.pdf? sequence=1

59. Shum, P., Bove, L., \& Auh, S. (2008). Employees' affective commitment to change: The key to successful CRM implementation. European Journal of Marketing, 42(11/12), 1346 - 1371. DOI: http://dx.doi.org/10.1108/03090560810903709

60. Sikdar, A.,\& Payyazhi, J. (2014). A process model of managing organizational change during business process redesign. Business Process Management Journal, 20(6), 971 - 998. DOI: http://dx.doi.org/10.1108/BPMJ-02-2013-0020

61. Stebbins, M.W., Shani, A.B.R., Moon, W., \& Bowles, D. (1998). Business process reengineering at Blue Shield of California: the integration of multiple change initiatives. Journal of Organizational Change Management, 11(3) 216 - 232. DOI: http://dx.doi.org/10.1108/09534819810216256

62. Taher, N.B., \& Krotov, V. (2016). Business Process Reengineering: Addressing sources of resistance and sabotage tactics. Journal of Competitiveness Studies, Indiana, 24(3), 145-163.

63. Talwar, R. (1993). Business Reengineering-A strategy driven approach. Long Range Planning, 26 (6), 22-40. DOI: http://dx.doi.org/10.1016/0024-6301(93)90204-S

64. Van der Aalst, W.M.P., La Rosa, M.,\& Santoro, F.M. (2016). Business Process Management. Don't Forget to Improve the Process! Bus Inf Syst Eng, 58(1), 1-6. DOI: https://doi.org/10.1007/s12599-015-0409-x

65. Warbhuwan, N.C. (2018). Strategic Human Resource Management in Public and Private Banks of Latur District: A Relative Exploration. Retrieved fromhttps://books.google.co.in/books?id=-S9RDwAAQBAJ

66. Watts, J. (1994). Dr Michael Hammer - the business change and re-engineering interview. Business Change and Reengineering, 1(4), 5-9.

67. Wells, M. G. (2000). Business process re $\square$ engineering implementations using Internet technology. Business Process Management Journal, 6(2), 164 - 184. DOI: http://dx.doi.org/10.1108/14637150010321303

68. Willmont, H. (1994). Business process reengineering and human resource management. Personnel Review, 23(3), 34-46. DOI: http://dx.doi.org/10.1108/00483489410064559

69. Willmont, H. (1995). The odd couple? Reengineering business processes; managing human relations. New Technology, Work and Employment, 10(2), 89-98. DOI: http://dx.doi.org/10.1111/j.1468-005X.1995.tb00008.x.

70. Xiang, J., Archer, N., \& Detlor, B. (2014). Business process redesign project success: the role of socio-technical theory. Business Process Management Journal, 20(5), 773 - 792. DOI: http://dx.doi.org/10.1108/BPMJ-10-2012-0112

71. Zucchi, F., \& Edwards, J. S. (1999). Human resource management aspects of business process reengineering: a survey. Business Process Management Journal, 5(4), 325 - 344. DOI: http://dx.doi.org/10.1108/14637159910297376

72. Zucchi, F., \& Edwards, J.S. (2000). How similar are human resource management practices in re $\square$ engineered organizations? Business Process Management Journal, 6(3), 214 - 223. DOI: http://dx.doi.org/10.1108/14637150010325426 
